\title{
Dental Anomalies among Patients with Malocclusion- A Cross Sectional Study
}

\author{
Sheloni $\mathrm{M}^{1}$, Nadeem $\mathrm{MA}^{1}$, Adil Ahmed $\mathrm{MA}^{2}, \mathrm{Anu} \mathrm{V}^{2}$ \\ ${ }^{I}$ (Interns, Sathyabama University Dental College and Hospital, India) \\ ${ }_{2}^{2}$ (Readers, Department of Public Health Dentistry, Sathyabama University Dental College and Hospital, India)
}

\begin{abstract}
The dental anomaly is a very important predecessor for the development of malocclusion in the oral cavity, according to the recent evidences which showed an increased prevalence of at least one dental anomaly among patients with malocclusion. A total of 200 subjects in the age group of 12 to 20 years were selected randomly for the study. Malocclusion was assessed and classified based on Angle's classification of malocclusion. The dental anomalies that were assessed are agenesis, dens invaginatus, dens evaginatus, impaction, transposition, submerged teeth, taurodontism, microdontia, macrodontia, dilacerations, enamel hypoplasia, supernumerary teeth, ectopic eruption, retained deciduous, fused root, others such as cusp of carabelli, protostylid. Highest number of patients was affected by class I malocclusion (54 patients) followed by class II sub div (46 patients), Ectopic eruption is identified to be the most common dental anomaly $25.5 \%$ (51 out of 200).
\end{abstract}

Keywords: Dental Anomaly, Ectopic Eruption, Malocclusion

\section{Introduction}

The eruption of the teeth is a complex phenomenon beginning from the origin of a tooth germ followed by the development of the teeth until they erupt into the oral cavity. Any variation in these delicate sequential events will cause improper eruption pattern, malformation of tooth and malocclusion. The causative factors for these disorders are disturbances in embryological development, growth disturbances, disturbances of dental development (dental anomalies), genetic and environmental influences[1].The anomalies emerge due to these cause are Agenesis, Dens evaginatus, Dens invaginatus, Impaction, Transposition, Submerged teeth, Taurodontism, Microdontia, Macrodontia, Dilacerations, Enamel hypoplasia, Supernumerary teeth, Ectopic eruption, Retained deciduous and Fused root[2].

The dental anomaly is a very important predecessor for the development of malocclusion in the oral cavity, according to the recent evidences which showed an increased prevalence of at least one dental anomaly among patients with malocclusion such as Uslu et al[1] in his study found that $40.3 \%$ of 900 orthodontic patients had at least one dental anomaly, Nayar et al[4] in his study reported that $35.1 \%$ had at least one dental anomaly. The prevalence rate of dental anomaly in India is $36.7 \%$ out of 4133 patients were examined [5]. Since there is a lack of data related to dental anomaly and its relationship with malocclusion especially in South Indian population, we have designed and conducted this cross- sectional study among school going children in Chennai.

\section{Materials and methods}

A total of 200 subjects in the age group of 12 to 20 years and who are willing to participate were included in the study. Subjects with the history of traumatic tooth, previous dental treatment like orthodontic treatment, prosthodontic, endodontic treatment, endocrine disorder were excluded. Ethical clearance was obtained from the Institutional Review Board and the School authorities and informed consent was obtained from the parents/guardian of the subjects before the onset of the study.

Malocclusion was assessed and classified based on Angle's classification of malocclusion[1] .The dental anomalies that were assessed are agenesis, dens invaginatus, dens evaginatus, impaction, transposition, submerged teeth, taurodontism, microdontia, macrodontia, dilacerations, enamel hypoplasia, supernumerary teeth, ectopic eruption, retained deciduous, fused root, others such as cusp of carabelli, protostylid. Radiographic investigation was carried out for the subjects whose dental anomaly required confirmation. Since dental anomalies like dens invaginatus, impaction, taurodontism, dilacerations, fused root can only be confirmed radiographically.

The data collected was entered in windows excel sheet 2010 and statistical analysis was carried out using SPSS version 11. Frequency distribution was calculated and chi square test was used to investigate the presence of any association between dental anomalies and malocclusion. The level of significance was set as $0.05 \%$. 


\section{Results}

A total of 200 patients were examined, out of which $(81 \%)$ had atleast one dental anomaly. Most of the patients were female (58\%). The average age of the patients was $14.76 \pm 2.75$ with the median age of 14 .

Highest number of patients were affected by class I malocclusion (54 patients) followed by class II sub div (46 patients) (Figure 1), Ectopic eruption is identified to be the most common dental anomaly $25.5 \%$ (51 out of 200), no patients were diagnosed with Dens invaginatus and fused roots (Figure 2).

In association between gender and types of dental anomalies it is evident that there are no association between gender and most of the dental anomalies, though two dental anomalies (macrodontia and supernumerary teeth ) has statistically significant results due to low volume it is rejected (Table 1).

In association between age and types of dental anomalies it is evident that there are no association between age and most of the dental anomalies, however dens evaginatus has statistical significant association with age, though taurodontism anomalies have statistically significant results due to low volume it is rejected (Table 2).

In association between malocclusion and types of dental anomalies it is evident that dens evaginatus and ectopic eruption anomalies have statistical significant association with malocclusion, however most of the other dental anomalies have no association with malocclusion (Table 3).

\section{Figures and Tables}

Figure 1: Frequency of Malocclusion

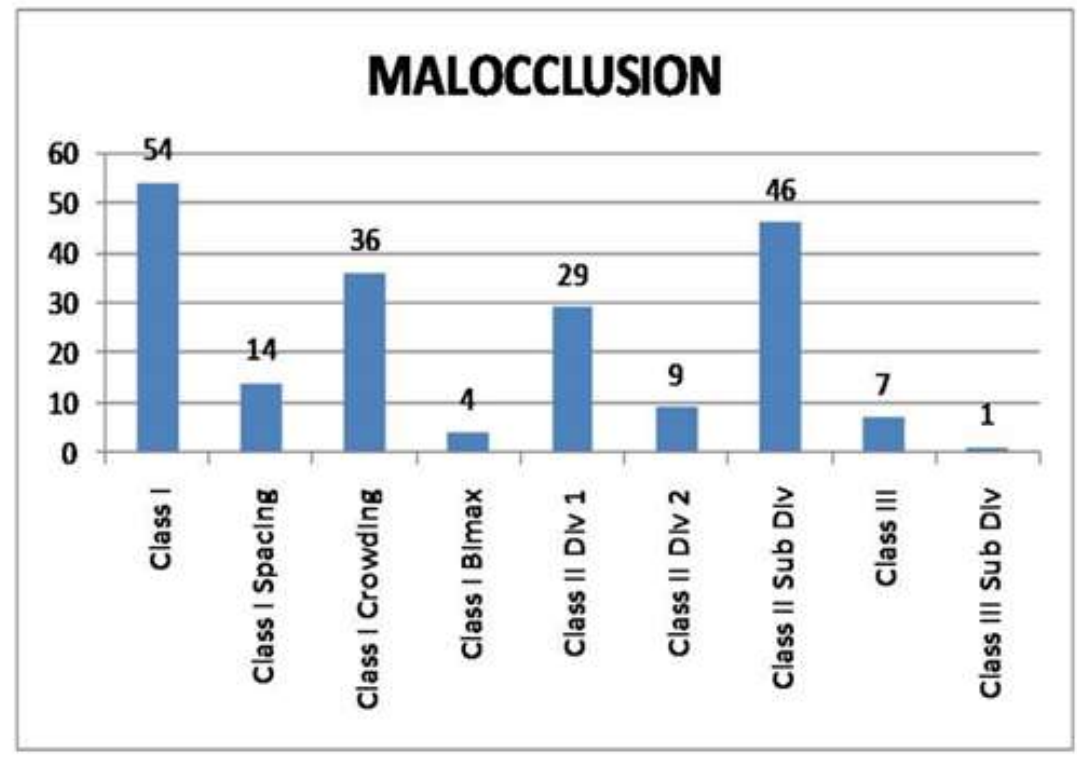

Figure 2: Frequency of Dental Anamoly

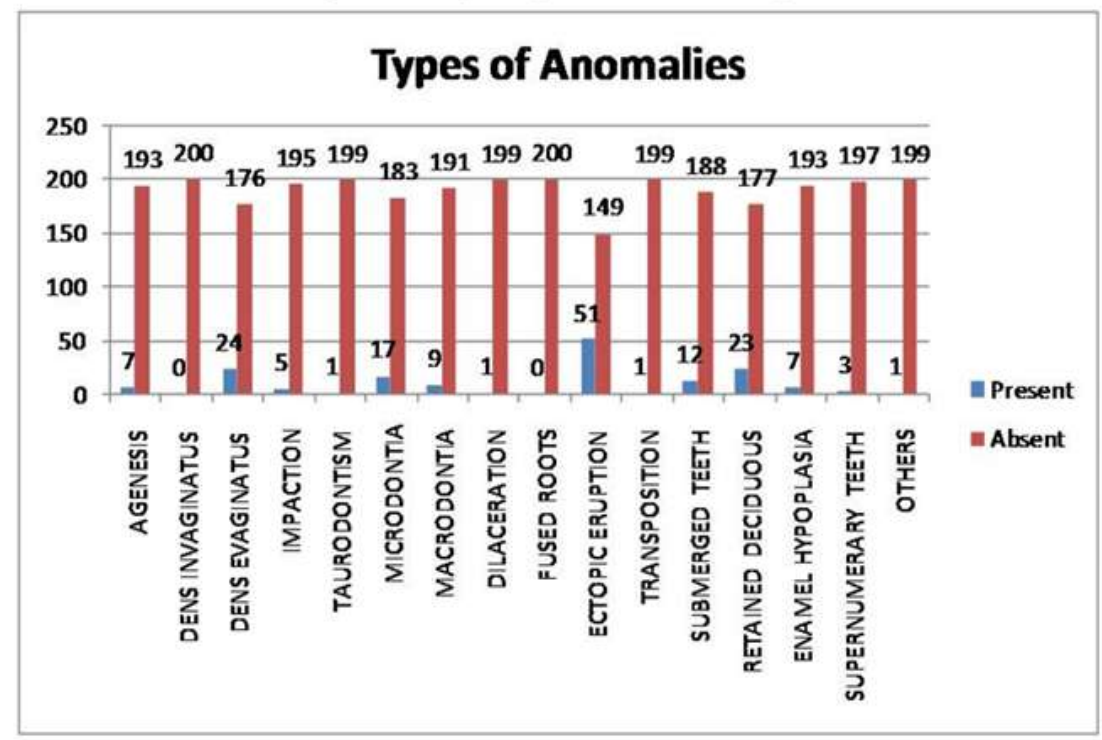


Table1: Association between Sex and Types of Dental Anomalies

\begin{tabular}{|c|c|c|c|c|c|}
\hline & \multicolumn{3}{|c|}{ Sex } & \multicolumn{2}{|c|}{ Pearson chi-square } \\
\hline & Male & Female & Total & Value & Siguifleance \\
\hline Agenesis & 3 & 4 & 7 & 0.002 & 0.963 \\
\hline $\begin{array}{l}\text { Delas } \\
\text { invaginatus }\end{array}$ & 0 & 0 & 0 & NA & NA \\
\hline $\begin{array}{l}\text { Dens } \\
\text { evaginafus }\end{array}$ & 9 & 15 & 24 & 0.227 & 0.634 \\
\hline Impartion & 4 & 1 & 5 & 3.0 .4 & 0.081 \\
\hline Tatuodontism & 0 & 1 & 1 & 0.728 & 0.394 \\
\hline Microdontia & 6 & 11 & 17 & 0.343 & 0.558 \\
\hline Macrodontia & 7 & 2 & 9 & 4.952 & 0.026 \\
\hline Dilaceration & 0 & 1 & $\mathbf{1}$ & 0.728 & 0.394 \\
\hline Fused roots & 0 & 0 & 0 & NA & NA \\
\hline $\begin{array}{l}\text { Ectopic } \\
\text { eruption }\end{array}$ & 17 & 34 & 51 & 2.111 & 0.146 \\
\hline Transposition & 0 & 1 & 1 & 0.728 & 0.394 \\
\hline $\begin{array}{l}\text { Submerged } \\
\text { teeth }\end{array}$ & 6 & 6 & 12 & 0.335 & 0.562 \\
\hline $\begin{array}{l}\text { Retained } \\
\text { decidnous }\end{array}$ & 7 & 16 & 23 & 1.427 & 0.232 \\
\hline $\begin{array}{l}\text { Enamel } \\
\text { hypoplasia }\end{array}$ & 3 & 4 & 7 & 0.002 & 0.963 \\
\hline $\begin{array}{l}\text { Superusumerary } \\
\text { teeth }\end{array}$ & 3 & 0 & 3 & 4.206 & 0.040 \\
\hline Others & 1 & 0 & 1 & 1.388 & 0.239 \\
\hline
\end{tabular}

Table2: Association between Age and Types of Dental Anomalies

\begin{tabular}{|c|c|c|c|c|c|c|c|c|c|c|c|c|}
\hline & \multicolumn{10}{|c|}{ Age } & \multicolumn{2}{|c|}{ Pearson chi square } \\
\hline & 12 & 13 & 14 & 15 & 16 & 17 & 18 & 19 & 20 & Total & Value & Significance \\
\hline Agenesis & 1 & 4 & 0 & 0 & 0 & 1 & 0 & 1 & 0 & 7 & 10.617 & 0.224 \\
\hline $\begin{array}{l}\text { Dens } \\
\text { invaginatus }\end{array}$ & $\mathbf{0}$ & $\mathbf{0}$ & 0 & 0 & 0 & 0 & 0 & 0 & $\mathbf{0}$ & 0 & NA & $\mathbf{N A}$ \\
\hline $\begin{array}{l}\text { Deas } \\
\text { evaginatus }\end{array}$ & 1 & 4 & 0 & 1 & 0 & 2 & 9 & 7 & 0 & 24 & 26.998 & 0.001 \\
\hline Impaction & 0 & 1 & 0 & 0 & $\mathbf{0}$ & 1 & 1 & 1 & 1 & 5 & 12.412 & 0.134 \\
\hline Taurodontism & 0 & 0 & 0 & 0 & 0 & 0 & 0 & 0 & 1 & 1 & 49.246 & 0.000 \\
\hline Microdontia & 6 & 3 & 2 & 1 & 0 & $\mathbf{0}$ & 3 & 1 & 1 & 17 & 4.255 & 0.833 \\
\hline Macrodontia & 4 & $\mathbf{0}$ & $\mathbf{I}$ & 1 & 0 & 2 & 0 & 1 & 0 & 9 & 9.836 & 0.277 \\
\hline Dilaceration & 0 & $\mathbf{0}$ & 0 & 0 & 0 & 0 & 0 & 1 & 0 & 1 & 8.132 & 0.421 \\
\hline Fused roots & 0 & 0 & 0 & 0 & 0 & 0 & 0 & 0 & 0 & 0 & $\mathbf{N A}$ & $\mathbf{N A}$ \\
\hline $\begin{array}{l}\text { Ectopic } \\
\text { eraption }\end{array}$ & 19 & 12 & 8 & 0 & 1 & 3 & 3 & 5 & 0 & 51 & 13.554 & 0.094 \\
\hline Transposition & 0 & 1 & 0 & 0 & 0 & 0 & 0 & 0 & 0 & 1 & 4.907 & 0.767 \\
\hline $\begin{array}{l}\text { Submerged } \\
\text { teeth }\end{array}$ & 8 & 1 & 1 & 1 & 0 & 1 & 0 & 0 & $\mathbf{0}$ & 12 & 11.552 & 0.172 \\
\hline $\begin{array}{l}\text { Retained } \\
\text { deciduous }\end{array}$ & 8 & 7 & 2 & 0 & 1 & 1 & 1 & 3 & 0 & 23 & 14.68 & 0.066 \\
\hline $\begin{array}{l}\text { Enamel } \\
\text { hypoplasia }\end{array}$ & 4 & 1 & 1 & 0 & 0 & 0 & 1 & 0 & 0 & 7 & 3.322 & 0.913 \\
\hline $\begin{array}{l}\text { Supernumerasy } \\
\text { teeth }\end{array}$ & 1 & 0 & 1 & 0 & 0 & 1 & 0 & 0 & 0 & 3 & 5.484 & 0.705 \\
\hline Others & 1 & 0 & 0 & 0 & 0 & 0 & 0 & 0 & 0 & 1 & 2.237 & 0.973 \\
\hline
\end{tabular}

NA-NOT APPLICABL.F 
Table 3: Association between Malocclusion and Types of Dental Anomalies

\begin{tabular}{|c|c|c|c|c|c|c|c|c|c|c|c|c|}
\hline & \multicolumn{10}{|c|}{ Malocclusion } & \multicolumn{2}{|c|}{$\begin{array}{l}\text { Pearson chi- } \\
\text { square }\end{array}$} \\
\hline & $\begin{array}{l}\text { Clas } \\
\text { sI }\end{array}$ & $\begin{array}{l}\text { Class } \\
\text { I } \\
\text { paci } \\
\text { ng }\end{array}$ & $\begin{array}{l}\text { Class I } \\
\text { crowdi } \\
\text { ng }\end{array}$ & $\begin{array}{l}\text { Clas } \\
\text { sI } \\
\text { bim } \\
\text { ax }\end{array}$ & $\begin{array}{l}\text { Clas } \\
\text { sII } \\
\text { div } \\
1\end{array}$ & $\begin{array}{l}\text { Clat } \\
\text { ss } \\
\text { II } \\
\text { div } \\
2 \\
\end{array}$ & $\begin{array}{l}\text { Class II } \\
\text { subdivis } \\
\text { lon }\end{array}$ & $\begin{array}{l}\text { Clas } \\
\text { s III }\end{array}$ & $\begin{array}{l}\text { Class } \\
\text { III } \\
\text { sub } \\
\text { divisi } \\
\text { ou } \\
\end{array}$ & $\begin{array}{l}\text { Tota } \\
\text { I }\end{array}$ & Value & $\begin{array}{l}\text { Siguifica } \\
\text { nce }\end{array}$ \\
\hline Agenesis & 2 & 2 & 1 & 0 & 0 & 1 & 1 & 0 & 0 & 7 & 8.154 & 0.419 \\
\hline $\begin{array}{l}\text { Dens } \\
\text { invaginatu } \\
\text { s }\end{array}$ & 0 & 0 & 0 & 0 & 0 & 0 & 0 & 0 & 0 & 0 & NA & NA \\
\hline $\begin{array}{l}\text { Dens } \\
\text { evaginatus }\end{array}$ & 2 & 0 & 4 & 1 & 11 & 2 & 1 & 2 & 1 & 24 & $\begin{array}{l}38.81 \\
2 \\
\end{array}$ & 0.000 \\
\hline Impaction & 2 & 0 & 2 & 0 & 0 & 0 & 1 & 0 & 0 & 5 & 3.361 & 0.910 \\
\hline $\begin{array}{l}\text { Taurodonti } \\
\sin \end{array}$ & 0 & 0 & 0 & 0 & 1 & 0 & 0 & 0 & 0 & 1 & 5.926 & 0.656 \\
\hline $\begin{array}{l}\text { Microdonti } \\
\text { a }\end{array}$ & 5 & 3 & 2 & 0 & 2 & 1 & 3 & 1 & 0 & 17 & 4.622 & 0.797 \\
\hline $\begin{array}{l}\text { Macroelont } \\
\text { ia }\end{array}$ & 2 & 1 & 2 & 0 & 0 & 2 & 2 & 0 & $\theta$ & 9 & 8.913 & 0.350 \\
\hline $\begin{array}{l}\text { Dilaceratio } \\
\text { u }\end{array}$ & 0 & 0 & 0 & 0 & 1 & 0 & 0 & 0 & 0 & 1 & 5.926 & 0.656 \\
\hline $\begin{array}{l}\text { Fused } \\
\text { roots }\end{array}$ & 0 & 0 & 0 & 0 & 0 & 0 & 0 & 0 & 0 & 0 & NA & NA \\
\hline $\begin{array}{l}\text { Ectopic } \\
\text { eruption }\end{array}$ & 5 & 2 & 14 & 3 & 5 & 5 & 15 & 2 & 0 & 51 & $\begin{array}{l}23.90 \\
2\end{array}$ & 0.002 \\
\hline $\begin{array}{l}\text { Transpositi } \\
\text { on }\end{array}$ & 0 & 0 & 0 & 0 & 0 & 1 & 0 & 0 & 0 & 1 & $\begin{array}{l}21.32 \\
9\end{array}$ & 0.006 \\
\hline $\begin{array}{l}\text { Submerged } \\
\text { teeth }\end{array}$ & 3 & 0 & 1 & 0 & 1 & 0 & 7 & 0 & 0 & 12 & $\begin{array}{l}10.18 \\
0\end{array}$ & 0.253 \\
\hline $\begin{array}{l}\text { Retained } \\
\text { deciduous }\end{array}$ & 9 & 1 & 2 & 0 & 0 & 2 & 9 & 0 & 0 & 23 & $\begin{array}{l}12.21 \\
2\end{array}$ & 0.142 \\
\hline $\begin{array}{l}\text { Enamel } \\
\text { hypoplasia }\end{array}$ & 1 & 0 & I & 0 & 1 & 1 & 3 & 0 & 0 & 7 & 4.220 & 0.837 \\
\hline $\begin{array}{l}\text { Superaum } \\
\text { erary teeth }\end{array}$ & 2 & 0 & 0 & 0 & 1 & 0 & 0 & 0 & 0 & 3 & 4.302 & 0.829 \\
\hline Others & $\theta$ & I & 0 & 0 & 0 & 0 & 0 & 0 & $\theta$ & 1 & $\begin{array}{l}13.35 \\
2\end{array}$ & 0.100 \\
\hline
\end{tabular}

\section{Conclusion}

Based on our results that nearly $81 \%$ of the patients had at least one dental anomaly, ectopic eruption (25.5\%) was the most common dental anomaly followed by dens evaginatus (12\%), retained deciduous $(11.5 \%)$, microdontia (8.5\%). Thongudomporn U and Freer TJ(1998) in their study which was carried out in a dental school, The University of Queensland stated that $74.8 \%$ of 111 orthodontic patients had atleast one dental anomaly and Dens Invaginatus was the most common dental anomaly[6]. There are various other studies that state the association between dental anomalies and malocclusion like Suwadee Kositbowornchai et al(2010) in his study done on Thai patients reported that nearly $38.6 \%$ of the subjects had atleast one dental anomaly[8] followed by Athari Al-Amiri et al(2013) in his study which was carried out in New York at Buffalo reported that nearly $20.4 \%$ of the subjects had atleast one dental anomaly with delayed eruption and impaction as the most common dental anomaly followed by agenesis and supernumerary tooth[7].

Various studies showed variations in the prevalence rate and common dental anomaly which may be due to the racial difference and varying study methodology. Our study showed the highest prevalence rate $81 \%$ of dental anomalies in patients with malocclusion when compared to other studies since our study was done mainly on clinical examination therefore in the further studies both clinical examination and pre-treatment diagnostic records should be considered to calculate the prevalence rate of dental anomalies.

In the present study there was no significance between gender and the types of dental anomalies which was in accordance with Thongudomporn and Freer (1998)[6] and Nayar R et al (2010)[4] studies. However other studies like Uslu et al (2009)[3] in his study reported that microdontia and ectopic eruption were common in females.

The present study showed an indicative association between age and the type of dental anomalies with ectopic eruption as the most common anomaly followed by Dens evaginatus, Retained deciduous, Microdontia and submerged teeth among 12,13,14,18 and 19 years of age but K S Dwijendra et al(2015)[9] in his study reported that the prevalence of dental anomalies was increasing with the years of age.

DOI: $10.9790 / 0853-1508043337 \quad$ www.iosrjournals.org $\quad 36 \mid$ Page


In association between dental anomalies and malocclusion Linn Haugland et al (2013)[10] in his study done on Norwegian school children states that the highest rate of anomalies were found in subjects with Class II followed by Class I malocclusion which was in accordance with the present study with the highest rate of dental anomalies in Class II subdivision followed by Class I Crowding and Class II Division 1, But Qalab Abbas et al(2010)[11] in his study reported the highest rate of dental anomalies in Class I group followed by Class II Division 2, Class II Division1 and Class III group.

\section{Acknowledgements}

We are thankful to Dr. B.Pavani, Ms. R.Karthika, Ms. S.Sumaiyya, Ms. A.Vennila and Mr. Selwin Gabriel Samuel for their contribution towards the study and for making the study a successful one.

\section{References}

[1]. Proffit WR, Fields HW, Sarver DM. Contemporary Orthodontics,4th edition, The Etiology Of Orthodontic Problems, Mosby Elsevier 2007; 130.

[2]. Shafer, Hine, Levy. Shafers- Text book of Oral Pathology,7th edition, Developmental Disturbances of Oral and Para oral Structures, Mosby Elsevier 2012; 39-59.

[3]. Uslu O, Akcam MO, Evirgen S, Cebeci L. Prevalance Of Dental Anomalies In Various Malocclusion. Am J Orthod Dentofacial Orthop 2009; 135 ( 3): 328-325.

[4]. Nayar R, Kapoor P, Nayar AK, Singh H. Dental Anomalies, Various Arch Form and Different Malocclusion- Is There A Correlation. Indian J Dent 2010; 3(1): 91-97.

[5]. Santhosh P, Bharati D, Sumita K, Farzan R. Prevalence Of Dental Anomalies In Indian Population. Journal of Clinical Experimental Dentistry 2013; 5(4): 183-186.

[6]. Thongudomporn U, Freer TJ. Prevalence of Dental Anomalies in Orthodontic Patients. Aust Dent J 1998; 43(6): 395-398.

[7]. Al- Amiri A, Tabbaa S, Pretson CB, Al-Jewair T. The Prevalence of Dental Anomalies in Orthodontic Patients at the State University of New York at Buffalo. JCDP 2013; 14(3): 518- 523

[8]. Kositbowornchai S, Keinprasit C, Poomat N. Prevalence And Distribution of Dental Anomalies In Pre-treatment Orthodontic Thai Patients. KDJ 2010; 13(2): 92-99.

[9]. Dwijendra KS, Parikh V, George SS, Kukkunuru GT, Chowdary. Association of Dental Anomalies With Different Types of Malocclusion In Pre -treatment Orthodontic Patients. Journal of International Oral Health 2015; 7 (6): 61-64.

[10]. Haugland L, Storesund T, Vandevska-Radunovic V. Prevalence of Dental Anomalies in Norwegian School Children. Open Journal of Stomatology 2013; 36: 329-333.

[11]. Abbas Q, Aslam A, Naeem A, Amjad M. Frequency of dental Anomalies in various malocclusions in Orthodontic Patients. Pakistan Oral and Dental Journal 2010; 30(1): 119-122.

[12]. Basdra EK, Magdalini N, Kiokpasoglou and Komposch G, Congenital Tooth Anomalies and Malocclusions: A Genetic Link. Eur J Orthod 2001; 23(2): 145-152.

[13]. Brook AH. A Unifying Etiological Explanation for Anomalies of Human Tooth Number and Size. Arch Oral Biol 1984; 29(5): 373378 .

[14]. Kotsomitis N, Dunne MP, Freer TJ. A Genetic Aetiology for Some Common Dental Anomaly. A Pilot Twin Study. Aust Orthod J 1996; 14(3): 172-178.

[15]. Peck S, Peck L, Kataja M. Class II Division 2 Malocclusion. A Heritable Pattern of Small Teeth in Well Developed Jaws. Angle Orthod 1998; 68 (1):9-20.

[16]. Kumar P, Brig SML, Kotwal SMA, Mitra R. Prevalence Of Malocclusion And Orthodontic Treatment Need In School Children-An Epidemiological Study. Med J Armed Forces India 2013; 69(4): 369-379.

[17]. Ghabanchi J, Haghnegahdar AA, Khodadazadeh SH, Haghnegahdar S. A Radiographic and Clinical Survey of Dental Anamolies In Patients Referring To Shiraz Dental School. Shiraz Univ Dent J 2010; 10 (suppl): 26-31. 